\title{
Pollution Characteristics and Risk Assessments of Mercury in the Soil of the Main Urban Regions in a Typical Chinese Industrial City: Changchun
}

\author{
Zhaojun Wang ${ }^{1,2,3}$, Lei Wang ${ }^{1,2}$, Tingting Xiao ${ }^{1}$, Tianle Yu ${ }^{1}, \mathrm{Xu} \mathrm{Li}^{1}$, \\ Zhanhui Tang1,2,3, Gang Zhang ${ }^{1,3,4}$ * \\ ${ }^{1}$ School of Environment, Northeast Normal University, Changchun Jilin, China \\ ${ }^{2}$ State Environmental Protection Key Laboratory of Wetland Ecology and Vegetation Restoration, \\ Changchun Jilin, China \\ ${ }^{3}$ Key Laboratory of Vegetation Ecology, Ministry of Education, Northeast Normal University, Changchun Jilin, China \\ ${ }^{4}$ Institute of Grassland Science, Northeast Normal University, Changchun Jilin, China
}

Received: 2 October 2020

Accepted: 30 November 2020

\begin{abstract}
As a typical industrial city in northeastern China, the environmental conditions of the soil in Changchun City face high ecological risks. In the present study, in order to more fully understand the characteristics of the soil mercury content and its related health risks in the main urban areas of Changchun City, the pollution degrees were evaluated using the data of land accumulation indexes $\left(I_{g e o}\right)$, potential ecological risk indexes $(E r)$, and health risk assessment methods. The mercury content (TSM) levels in the urban soil, along with the atmospheric mercury content (TGM) levels, were analyzed. The results showed that the mean value of the mercury content in the soil in Changchun City was $0.0569 \pm 0.103 \mathrm{mg} / \mathrm{kg}$, and the concentration range was between 0.0052 and $1.3240 \mathrm{mg} / \mathrm{kg}$. It was found that the mercury content levels in nearly $70 \%$ of the soil samples exceeded the background value of soil $(0.040 \mathrm{mg} / \mathrm{kg})$. In addition, the atmospheric mercury concentration at $0 \mathrm{~cm}$ was determined to be directly related to soil mercury content $(P=0.000532)$. In addition, the atmospheric mercury content of $0 \mathrm{~cm}$ was observed to be positively correlated with the distribution of the atmospheric mercury content at $100 \mathrm{~cm}(P=0.000524)$. The mercury content levels in the soil were found to vary from different directions, with the mercury content found to be the highest in the southeastern section of the city. However, there were no significant differences in the mercury content of any direction. The $I_{\text {geo }}$ showed that $25.0 \%$ of the sample points were polluted. The unsanitary areas were mainly concentrated in the southwestern and southeastern sections of the city. The mercury content levels in the soil of Changchun City ranged from pollution-free to moderate pollution levels overall. The $\mathrm{Er}$ indicated that the potential ecological risk level was high in the northwestern and southeastern sections of Changchun City. However, the soil mercury levels in Changchun City presented a low level of ecological risk overall.
\end{abstract}

*e-mail: zhangg217@nenu.edu.cn 
The average values of the non-carcinogenic risks $(H Q)$ and the total non-carcinogenic risk assessment indexes $(H I)$ in all directions within Changchun City were determined to be far less than 1 . Therefore, it was concluded that the soil mercury levels were not potentially harmful to human health.

Keywords: mercury (Hg), urban soil, pollution characteristics, risk assessments, Changchun City

\section{Introduction}

The soil pollution caused by heavy metals, along with their associated harmful ecological and health effects, are currently of growing concern. During the last century, the residents of Japan's Kumamoto Minamata Village experienced "Minamata Disease", which was the world's first mercury pollution incident caused by an environmental pollution event. As a result, mercury pollution has aroused widespread concerns throughout the world [1]. Heavy metal mercury is a highly toxic non-essential element and is considered to be one of the most toxic substances affecting the health of organisms. In the environment, mercury tends to accumulate in organisms, sometimes resulting in fatal damage to those organisms [2]. At the same time, mercury pollution can migrate with water and the atmosphere, and remain in the environment for long periods of time. Therefore, mercury pollution has a wide range of influence [3-4]. As a result, mercury pollution has been listed as a global pollutant by the United Nations Environment Program [5-8]. Environmental soil can form reservoirs for mercury and mercury pollution in the soil is known to have latent, persistent, acutely toxic, and irreversible characteristics [9]. In addition, mercury may become widely distributed and accumulated in various ecosystems [10]. Soil mercury pollution is now considered to be an important part of the global mercury pollution situation.

With the increasing number and density of urban populations, the accumulation of mercury in the soil of urban areas has one of the main ways in which dense urban populations have become exposed to mercury pollution. Urban soil environments are subjected to heavy metal input from atmospheric deposition, irrigation water, industrial activities, and natural sources. This is particularly true for heavy metal mercury [11-14]. Due to the fact that mercury can affect the health of the urban residents, it has become necessary to understand the status of city soil environments with regard to mercury accumulation levels. At the present time, the problems related to mercury pollution in urban soil environments have one of the main focuses of studies regarding urban environmental issues, and a great deal of work has been completed in that area [15-21]. According to the previous study results, the mercury pollution in soil is considered to mainly originate from the following urban sources [7, 22]:

1) Burning of fossil fuels: Coal-fired power plants and heating plants are the single largest source of atmospheric mercury emissions. Mercury is eventually returned to the soil through atmospheric subsidence, and the production of energy from fossil fuels, such as oil refining. In addition, vehicle emissions also result in increased pollution indexes.

2) Smelting of non-ferrous metals: The raw materials used in nonferrous metal smelting contain mercury, and the mercury element used in nonferrous metal smelting processes will appear in the form of elemental or compounds with the discharge of smelting smoke, causing mercury pollution to air, water, and soil.

3) Production of items containing mercury: Some medical instruments used in daily life, as well as such daily articles as blood pressure meters, thermometers, fluorescent lamps, electrical switches, pressure sensors, and so on. Cement products also contain mercury.

4) Emissions caused by waste treatment and incineration processes: Various waste treatments in landfills also produce mercury pollution.

Although a great deal of attention has been given to the risks of heavy metal pollution in agricultural soil and industrial land, less is currently known regarding metal pollution in Chinese urban soil [2324]. This information is identified as being critical, considering the continuous exposure to urban residents, and especially children, to the accumulated metals in urban soil [25-29]. Such exposure may take the forms of oral ingestion, inhalation, or dermal contact. At the present time, Chinese researchers have investigated the mercury content levels in the soil of Hulun Buir [30], Zhongshan [31], Guilin [32], and Tianjin [33], as well as some of the counties in Shanxi Province [34] and other cities in China. On an international scale, the status of soil mercury accumulation in Palermo (Sicily) [19], Glasgow [18], Khabarovsk [20], and Avero [21] have been examined. However, while the previous studies have largely focused on a single type of urban soil, comprehensive risk assessments of metals in the major types of urban soil in China continue to be lacking [35]. Therefore, in the present study, the key research focus was placed on the current content levels of heavy metal mercury in urban soil and risk assessments of the negative health impacts of mercury on urban residents, including adults and children.

The main objective of this study was to assess the risks of heavy metal mercury pollution in the soil of Changchun, which is a typical industrial city in northeastern China. Previously, researchers have conducted studies on the sources of Changchun's surface soil mercury. The results revealed that the $\mathrm{Hg}$ mainly originates from coal burning and industrial activities [36]. Therefore, Changchun is also considered to be one of the representative cities affected by 
industrial processes. It is believed that the adjustments of energy structures that have been applied to the formation of mercury pollution will still exist for a long period of time, and that they may have certain impacts on human living environments. Therefore, this study chose to discuss the situation of such impacts. Surface soil samples were collected in Changchun and their concentrations of heavy metal mercury and atmospheric mercury were analyzed. The ecological risks of the heavy metal $\mathrm{Hg}$ in the soil were assessed by calculating the geo-accumulation indexes [37-38] and the potential ecological risk indexes [39]. The associated health risks were then assessed by determining the levels of metal exposure through oral ingestion, inhalation, and dermal contact, and then calculating the hazard quotient $(H Q)$, and hazard index $(H I)$. The results of this study will contribute to a more comprehensive understanding of the risks arising from human exposure to heavy metal mercury in Chinese cities.

\section{Materials and Methods}

\section{Study Area}

The study area of Changchun is located in northeastern China, and is the capital of Jilin Province. Changchun City is the provincial capital of Jilin Province, with the geographic coordinates to

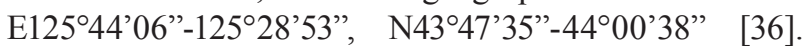
Changchun is located in the middle of a northeastern plain, and characterized by a continental monsoon climate. The duration of the hottest period is five months, with an annual average temperature of $4.6^{\circ} \mathrm{C}$; average wind speed of $4.2 \mathrm{~m} / \mathrm{s}$; and annual rainfall of $567 \mathrm{~mm}(70 \%$ of which occurs during the summer months) [40]. Changchun is an important base for China's automobile industry, agricultural product processing industry, science, education, culture, and trade. Its industries are mainly transportation equipment manufacturing, and its energy is derived mainly from the burning of coal [41]. By consulting Changchun City's master plan (2011 to 2020), this study selected designated urban areas as the research objects. Changchun's urban planning area $\left(391.1 \mathrm{~km}^{2}\right)$ included the Nanguan District; Chaoyang District; Kuancheng District; Erdao District; Luyuan District; economic and technological development zones; high-tech development zones; automobile net economic development zones; and economic and technological development zones, for a total of nine administrative regions. This study chose the People's Square as the center point, and then divided the main urban areas of Changchun into the following four directions: northwest, northeast, southwest, and southeast. The main urban area was selected as the research scope since it included both built-up areas and suburban areas. These were composed of the early development zones and new urban areas of Changchun City, which comprehensively reflected the basic characteristics of the urban spaces of the typical urban core area and peripheral expansion areas [42], as detailed in Fig. 1.

\section{Sampling and Analysis Processes}

In the current research investigation, the sample collection areas of the main urban areas and the urban-rural junctions of Changchun City were evenly distributed on a grid, which was then divided into a total of 80 sampling cells $(1 \mathrm{~km} \times 1 \mathrm{~km})$. However,
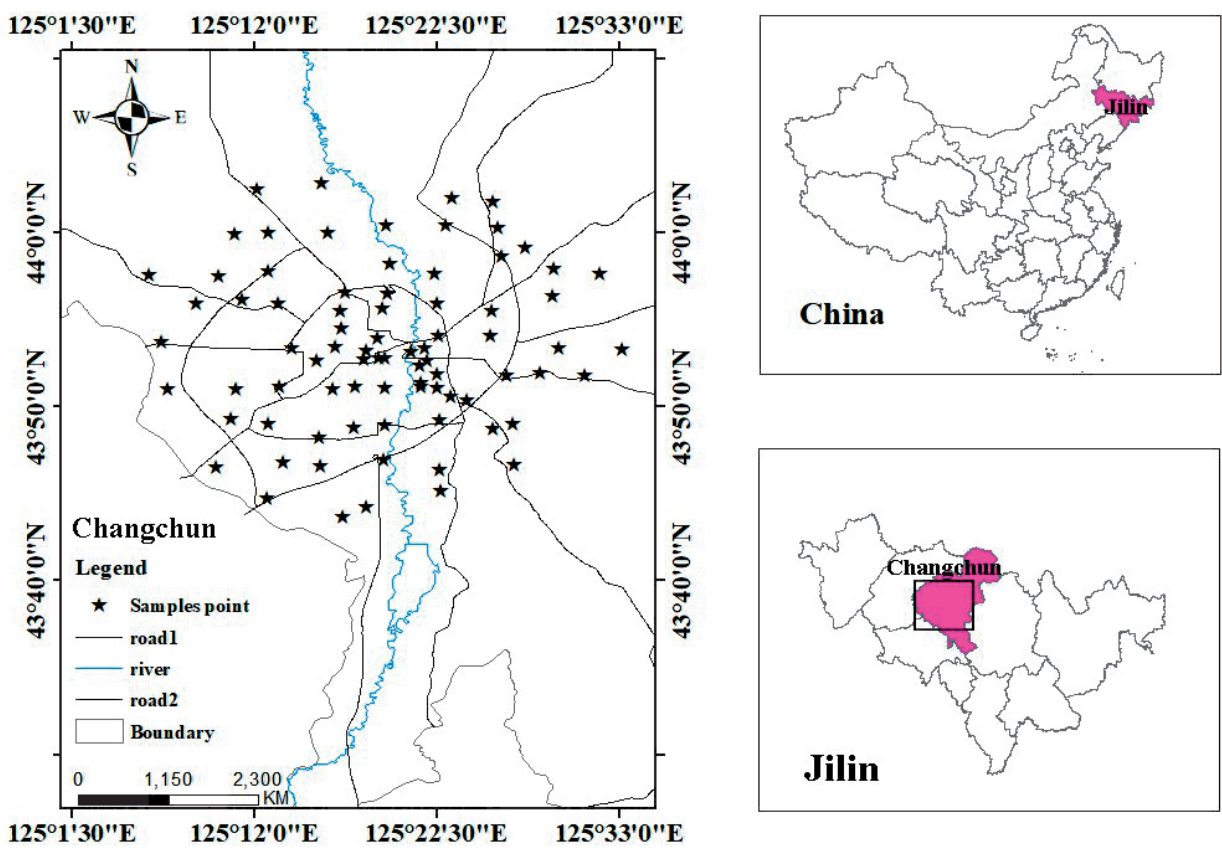

Fig. 1. Study area and sampling points. 
with consideration given to the actual sampling process, some points were deleted and adjusted within a small range. Finally, a location map of the sampling points was drawn according to the longitude and latitude of each sampling point, as shown in Fig. 1. Each sample was collected using a plug arrangement procedure. Five equal volume samples were collected in the range of $5 \mathrm{~m} \times 5 \mathrm{~m}$, and uniformly mixed into one sample. In addition, all of the samples were collected from the 0 to $10 \mathrm{~cm}$ surface soil layers, and any plants, dead branches, fallen leaves, rocks, sand grains, and so on were removed. The samples were sealed and stored in polyethylene bags, with each sample weighing approximately 500 g. For the soil samples obtained in areas without hardened sampling points, the dust removed within a certain area around the sampling points were taken as the test samples. Following the completion of the sample collection process, the samples were stored in a cool place until the analysis was completed.

In this study, a Zeeman LUMEX RA915 ${ }^{+}$was used for the determination of the mercury content levels in the air. It was found that when fit with UMA modules, it had the ability to realize both solid and liquid detections. All of the different types of sampling points were divided into two layers in the vertical direction in the air according to a range of $0 \mathrm{~cm}$ and $100 \mathrm{~cm}$, and an in-vehicle mercury meter (Zeeman LUMEX RA915 $)$ was used for the monitoring process according to the sample point sequence number. The atmospheric detection limit was $2 \mathrm{ng} / \mathrm{m}^{3}$. Each point was followed for six minutes. That is to say, each layer within each point was continuously monitored for 30 seconds, with one datum per 10 seconds, 6 cycles, and 18 parallel data per layer within each point, respectively.

The collected soil samples were dried under dark conditions, and then ground and passed through 80 mesh nylon sieves. The various soil samples were then bagged for the subsequent analysis process. The soil detection limit of the instrument adopted in this study was $0.005 \mathrm{mg} / \mathrm{kg}$. Then, using the national standard soil sample guidelines, the standard curves were obtained. Soil samples of $50 \mathrm{mg}$ to $200 \mathrm{mg}$ were weighed and placed into the soil sample detection port of the Zeeman LUMEX RA915 ${ }^{+}$via a quartz tank. The mercury content levels of the soil samples were measured, and parallel samples were obtained five times.

\section{Ecological Risk Assessment Processes}

\section{Geo-Accumulation Index $\left(I_{\text {ged }}\right)$}

The geo-accumulation index $\left(I_{\text {geo }}\right)$ is used to assess contamination levels of a specific metal in soil by evaluating the metal enrichment above the baseline or background values. In this study, the geo-accumulation index was calculated according to Eq. (1) [43-44] as follows:

$$
I_{\text {geo }}=\log _{2}\left[C_{n} /\left(K \times B_{n}\right)\right]
$$

...where $I_{\text {geo }}$ represents the ground accumulation index; $C_{n}$ is the measured concentration of mercury $(\mathrm{mg} / \mathrm{kg})$; $K$ indicates the modified index (which is generally 1.5 ) in order to take into account the changes in the background values which may have been caused by the differences in the rock characteristics in different locations; and $B_{n}$ denotes the municipal soil background value $(0.040 \mathrm{mg} / \mathrm{kg})$ [45].

\section{Potential Ecological Risk Index (Er)}

The assessments of potential ecological risks are considered to be one of the conventional methods for the ecological risk assessment index [46]. A quantitative method was previously developed, which includes a toxic reaction factor ( $T r$ ) [39]. The toxicity of each heavy metal can be quantitatively calculated using the aforementioned method. In this study, the potential ecological hazard coefficient $E r$ of the mercury in the study area was calculated according to Eq. (2):

$$
E r=\operatorname{Tr} \times C f=\operatorname{Tr} \times\left(C_{n} / C_{o}\right)
$$

...where $E r$ is the potential ecological harm coefficient of the mercury; $\operatorname{Tr}$ represents the toxicity coefficient of the mercury, which was set at 40 [47]; $C f$ corresponds to the toxic reaction of a particular metal by dividing the measured concentration of the actual heavy metal with its background level [48].

\section{Health Risk Assessments}

\section{Exposure Assessments}

$A D I$ indicators are generally used to assess the health risks of heavy metal pollution to humans, in which humans are exposed to heavy metals in soil via three main ways, namely ingestion, inhalation, and skin contact [49]. However, previous research results have shown that mercury can also be ingested as vapor [50]. In China, ingestion of soil particles has been found to be an important way in which urban populations come into contact with heavy metals [51-53]. During health risk assessment processes, the determination of the exposure factors and other related parameters is essential to accurately calculating the health risks. In addition to consulting the American Standards, this study was supplemented and modified according to the national conditions and regional characteristics of the study area [54]. Among those factors, the exposure frequency was modified to 350 days according to the national conditions of China [50]. The daily $A D I$ of metals in urban soil was computed according to Formulae (3) to (6) as follows:

The direct contact route of human skin:

$$
A D I_{\text {Skin intake }}=\frac{C \times S A \times A F \times A B S \times E F \times E D}{B W \times A T} \times 10^{-6}
$$


The direct oral ingestion route:

$$
A D I_{\text {Oral intake }}=\frac{C \times I F P \times E F \times E D}{B W \times A T} \times 10^{-6}
$$

The respiratory intake route:

$$
A D I_{\text {Breathing intake }}=\frac{C \times I R \times E F \times E D}{B W \times A T \times P E F}
$$

The mercury vapor intake route:

$$
A D I_{\text {Steam intake }}=\frac{\dot{C} \times I R \times E F \times E D}{B W \times A T \times V F}
$$

...where $A D I$ represents the chronic daily exposure $(\mathrm{mg} /(\mathrm{Kg} \cdot \mathrm{d})) ; \quad C$ is the measured concentration $(\mathrm{mg} / \mathrm{kg}) ; S A$ denotes the skin area $\left(\mathrm{cm}^{2} / \mathrm{d}\right)$ which may come in contact with soil, and the reference value is 5,000 $\mathrm{cm}^{2} / \mathrm{d}$ [55]; $A F$ indicates the adsorption coefficient of skin on soil $\left(\mathrm{mg} / \mathrm{cm}^{2}\right)$, and the reference value is $1 \mathrm{mg} / \mathrm{cm}^{2}$ [56]; $A B S$ is the skin respiration rate, and the reference value is 0.001 [55]; $E F$ indicates the exposure frequency $(\mathrm{d} / \mathrm{a})$, and the reference value is $350 \mathrm{~d} / \mathrm{a}$ [56]; $E D$ denotes the exposure duration (a), and the reference value is 25 a [54]; $B W$ indicates the body weight $(\mathrm{kg})$, and the reference value is $55.9 \mathrm{~kg}$ [55]; $A T$ represents the exposure cycle (d), and the reference value is $365 \times E D$ (d) [55]; IFP is the soil intake (mg/d), and the reference value is $114 \mathrm{mg} / \mathrm{d}$ [56]; $I R$ refers to the air intake $\left(\mathrm{m}^{3} / \mathrm{d}\right)$, and the reference value is $20 \mathrm{~m}^{3} / \mathrm{d}$ [56]; $P E F$ represents the production factor of the soil dust particles, and the reference value is $1.32 \times 10^{9} \mathrm{~m}^{3} / \mathrm{kg}$ [57]; and $V F$ is the evaporation coefficient $\left(\mathrm{m}^{3} / \mathrm{kg}\right)$, and the reference value is $32657.6 \mathrm{~m}^{3} / \mathrm{kg}$ [50].

\section{Non-Carcinogenic Risk Assessments}

Health risk assessments are generally divided into carcinogenic risk assessments and non-carcinogenic risk assessments. Non-carcinogenic risk assessments are generally carried out by mercury. In the present study, in order to assess the potential health risks associated with the non-carcinogenic effects of heavy metals in soil, the methodology provided by the United States Environmental Protection Agency was utilized. In terms of the hazard quotient $H Q$ [58], the risk factor $(H Q)$ was calculated as the ratio of the $A D I$ of a given metal to the reference dosage (RfD), as per Formula (7):

$$
H Q=\frac{A D I i}{R f D i}
$$

...where $A D I i$ is the chronic daily exposure $(\mathrm{mg} /(\mathrm{kg} \bullet \mathrm{d}))$; $R f D$ represents the reference dosage of heavy metal mercury $(\mathrm{mg} /(\mathrm{kg} \bullet \mathrm{d}))$, which is the maximum allowable content of a metal which has no harmful effects on human health [59].

$H I$ is often used to evaluate the non-carcinogenic effects of heavy metals. Therefore, the total noncarcinogenic risk values of mercury in different pathways can be expressed as $H I$, as per Formula (8):

$$
H I=\sum_{i}^{n} H Q
$$

When $H I$ or $H Q>1$, it is generally considered that there are potential non-carcinogenic risks. Meanwhile, when $H I$ or $H Q<1$, it is generally considered that the risks are small and can be potentially ignored.

\section{Results and Discussion}

\section{Metal Concentrations in the Soil}

The intuitive reflections of the mercury concentrations in soil within the main urban areas of Changchun City are shown in Table 1.

It was determined in this study that the mean mercury content in soil samples was $(0.0569 \pm 0.103) \mathrm{mg} / \mathrm{kg}$, and the concentrations ranged between 0.0052 and $1.3240 \mathrm{mg} / \mathrm{kg}$. The variations in the soil mercury content levels among the main urban areas of Changchun City were observed to be large. The background value [45] of the mercury in the soil in Changchun City was $0.040 \mathrm{mg} / \mathrm{kg}$. It was found that in nearly $70 \%$ of the 80 sample sites, the mercury levels had exceeded the soil background value, with the highest reaching levels nearly 8 times higher than the background value. The soil in the main urban areas of Changchun City had been preliminarily affected by exogenous mercury, and the soil layers in the different regions were contaminated with mercury to varying degrees. It was observed that when compared with other Chinese cities (Table 2), it can be seen that the urban soil in Guangzhou (a first-tier city) was the most seriously polluted by exogenous mercury. Therefore, it will be necessary to strictly control the artificial introduction of mercury in that area in order to avoid the destruction of the soil ecological environments as a result of mercury accumulation. Secondly, Chongqing, Xuzhou, Beijing, and Taiyuan were all found to be more seriously polluted by exogenous mercury than Urumqi, Changchun, Nanjing, and Tibet. Overall, Changchun City was determined to be less polluted by exogenous mercury when compared with other cities. However, vigilance will still be required in order to control the artificial introduction of mercury elements.

Table 1. Description of the mercury content levels in the soil of Changchun City ( $\mathrm{n}=400, \mathrm{mg} / \mathrm{Kg})$.

\begin{tabular}{|c|c|c|c|c|c|c|}
\hline Entire distance & Maximum & Minimum & Average & $95 \%$ UCL & Max/Min & Background \\
\hline 1.3188 & 1.3240 & 0.0052 & 0.0569 & 10.1797 & 254.6154 & 0.0400 \\
\hline
\end{tabular}


Table 2. Mercury content levels in the soil of other urban areas in China.

\begin{tabular}{|c|c|c|c|c|}
\hline City & Range & Average & Background & Reference \\
\hline Chongqing & 0.060 to 3.881 & 0.319 & 0.040 & (Li et al., 2006) [60] \\
\hline Beijing & 0.010 to 0.966 & 0.278 & 0.058 & (Han et al., 2015) [61] \\
\hline Guangzhou & 0.013 to 12.231 & 0.614 & 0.157 & (Guo et al., 1996) [62] \\
\hline Taiyuan & 0.040 to 0.297 & 0.105 & 0.098 & (Wang et al., 2005) [40] \\
\hline Xuzhou & 0.020 to 1.300 & 0.290 & - & (Zhu et al., 2014; Zhang., 1994) [63-64] \\
\hline Tibet & Unknown to 0.056 & 0.026 & 0.021 & (Xia et al., 1985; Hu et al., 2003) [65] \\
\hline Urumqi & 0.012 to 0.176 & 0.062 & 0.055 & (Huang et al., 2007) [66] \\
\hline Nanjing & 0.041 to 8.090 & 0.043 & 0.025 & \\
\hline
\end{tabular}

It was found that the $\mathrm{Hg}$ in Changchun City had mainly originated from coal burning and industrial activities [67]. In addition, previous related studies have found that a large number of mercury lamps, fluorescent lamps, and other gas discharging lamps are extensively used throughout the region, which are known to greatly increase the mercury content in surface soil layers. There are more than 64,000 streetlamps in Changchun, and nearly 6,500 lamps are replaced every year [68], thus creating a source of exogenous mercury. Moreover, such lighting devices are extensively used within the Changchun Industrial Park, logistic parks, thermal power plants, and cement factories, which has directly led to increases in exogenous mercury pollution [69].

\section{Relationship between the Soil Mercury \\ Concentrations and the Atmospheric Mercury Concentrations}

In this study's comparison of the atmospheric mercury concentration levels at $100 \mathrm{~cm}$ with that at $0 \mathrm{~cm}$ (Fig. 2), it was found that $72 \%$ of the sampling sites had concentrations of atmospheric mercury at $100 \mathrm{~cm}$ which were higher than those at $0 \mathrm{~cm}$. This was mainly attributed to the rapid construction and development of Changchun City in recent years, which has to the strengthening of urban heat island effects and stronger vertical convection of air [70-71]. It was determined that although the urban heat island circulation tends to be a weak mesosphere circulation, it often causes high weather impacts. For example, as one of the important types of circulation in urban boundary layers, it often affects the spread and diffusion of various pollutants. As a result, the pollutants in the atmosphere are not easily diffused and tend to settle on the surface areas [72]. In addition, such effects may also be caused by secondary dust. Since the majority of the sampling points in this study were located on roads with high traffic flow, the secondary dust phenomena was relatively serious, resulting in the atmospheric mercury content levels at $100 \mathrm{~cm}$ being higher than those observed at ground level. The results also indicated that road traffic is a primary source of heavy metal pollution in urban areas. It was confirmed through this study's analyses of the sampling points that the atmospheric mercury concentrations at $0 \mathrm{~cm}$ were directly related to the soil mercury content $(\mathrm{P}=0.000532)$. In addition, it was verified that the higher the mercury concentration in the atmosphere was, the higher the mercury content in the soil would be. Moreover, the results obtained in related research have shown that atmospheric mercury concentrations are significantly positively correlated with the soil mercury content levels, with a correlation coefficient of $0.741(\mathrm{n}=52)$ [73]. Also, it was found that the atmospheric mercury pollution had a major influence on the mercury accumulation levels in the surface soil layers.
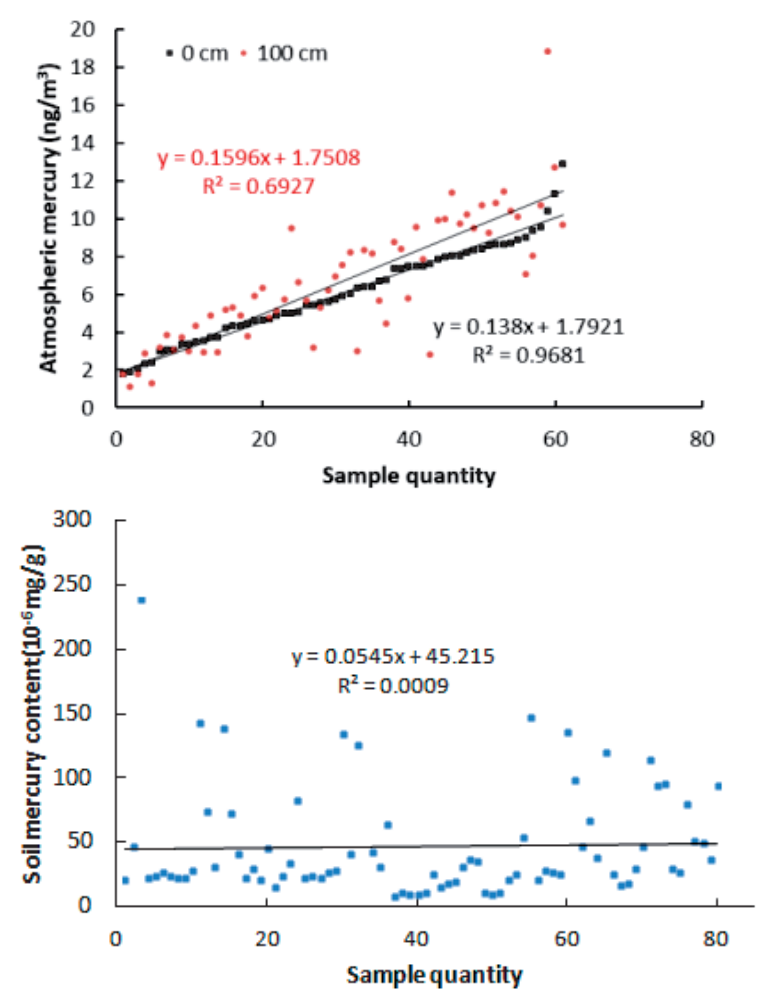

Fig. 2. Atmospheric mercury content and soil mercury content levels in the study area. 


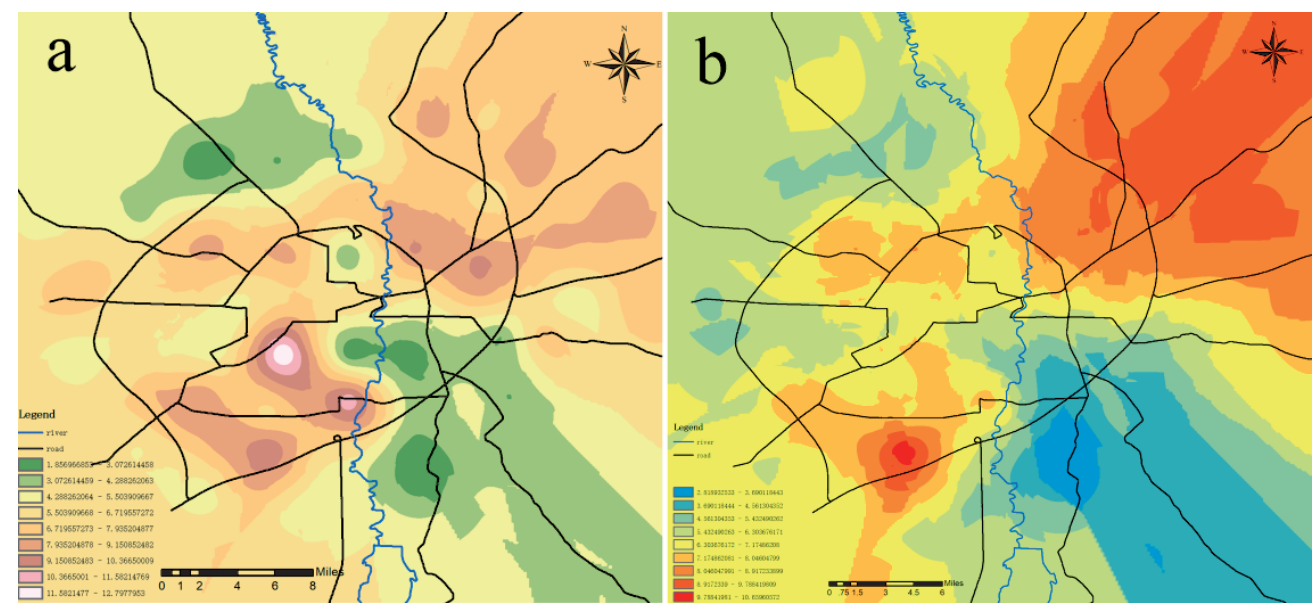

Fig. 3. Distribution map of the atmospheric mercury content at: a) $0 \mathrm{~cm}$; and b) $100 \mathrm{~cm}$.

In the current research investigation, a comparison was made of the distributions of mercury content in the atmosphere at $0 \mathrm{~cm}$ and $100 \mathrm{~cm}$, respectively (Fig. 3). It was found that there was a good correlation between the distributions $(\mathrm{P}=0.000524)$, with the mercury content at $100 \mathrm{~cm}$ higher than that observed at $0 \mathrm{~cm}$. Those findings indicated that atmospheric mercury deposition was the main source of the soil mercury content. Also, according to the mercury pollution index in Changchun City (thermal plants, medical apparatus, instrument factories, and so on), the distribution of the mercury content at $0 \mathrm{~cm}$ had mainly originated from heating companies, industrial and logistics parks, and transport and industrial parks in which the production processes involved the burning of coal. The waste gases and waste residue of such industrial areas generally contain different types of heavy metals, and those pollutants can be transferred to urban soil through dry or wet subsidence methods, such as deposition and enrichment in the soil nearby as the result of excessive amounts of heavy metal accumulation [74]. The areas with high mercury content at $100 \mathrm{~cm}$ were found to be mainly concentrated in the vicinity of the logistic parks and residential areas. This was mainly due to the large traffic flow in the logistic parks, with the mercury content of the atmosphere found to be related to the relatively dense traffic flow. The high mercury content levels near residential areas were generally affected by coal-burning heating and household garbage processes [75].

\section{Relationship between the Concentration Levels of Mercury in the Soil and the Wind Directions}

In order to study the influences of the different wind directions on the mercury content levels of soil in the main urban areas of Changchun City, a box chart and a variance analysis method were adopted to analyze the mercury content levels in the following four directions: northwest, northeast, southwest, and southeast. As shown in Fig. 4, there were differences observed in the soil mercury content levels among the four directions, with the highest mercury content found to be in the southeast direction. The results of this study's one-way ANOVA showed that the mercury content in the northeastern direction was greater than in the southwestern direction. However, there were no significant differences observed between the two $(\mathrm{P}=0.37>0.05)$. In addition, there were no significant differences observed in soil mercury content levels between the northeastern and northwestern directions $(\mathrm{P}=0.83>0.05)$, and no significant differences between the northeastern and southeastern directions $(\mathrm{P}=0.60>0.05)$. One-way ANOVA was performed in the northwest and southeast directions, with no significant differences found in the soil mercury content between those two directions $(\mathrm{P}=0.45>0.05)$. Furthermore, there were no significant differences observed between southwest and northwest $(\mathrm{P}=0.48>0.05)$ and southeast directions $(\mathrm{P}=0.15>0.05)$.

However, according to the data shown in Figs 3 and 4 , the soil mercury content levels in the southeast direction of Changchun City were relatively high.

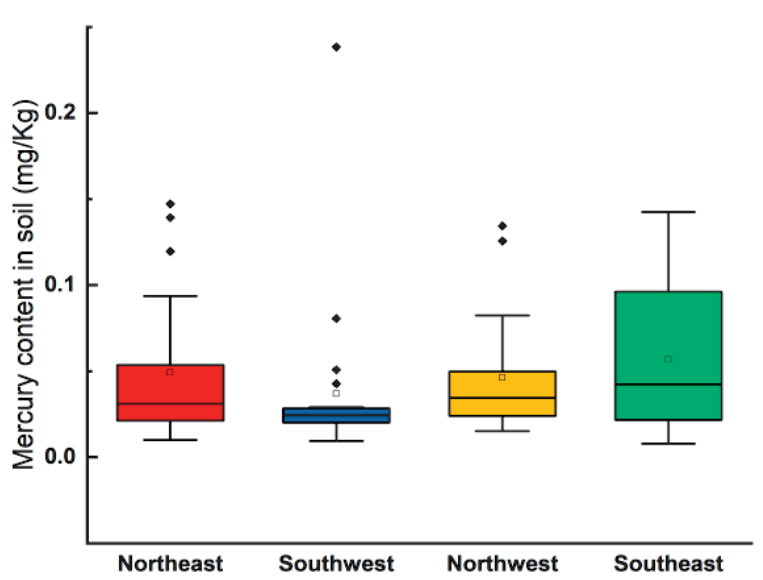

Fig. 4. Box chart of the mercury content levels in the different wind directions. 


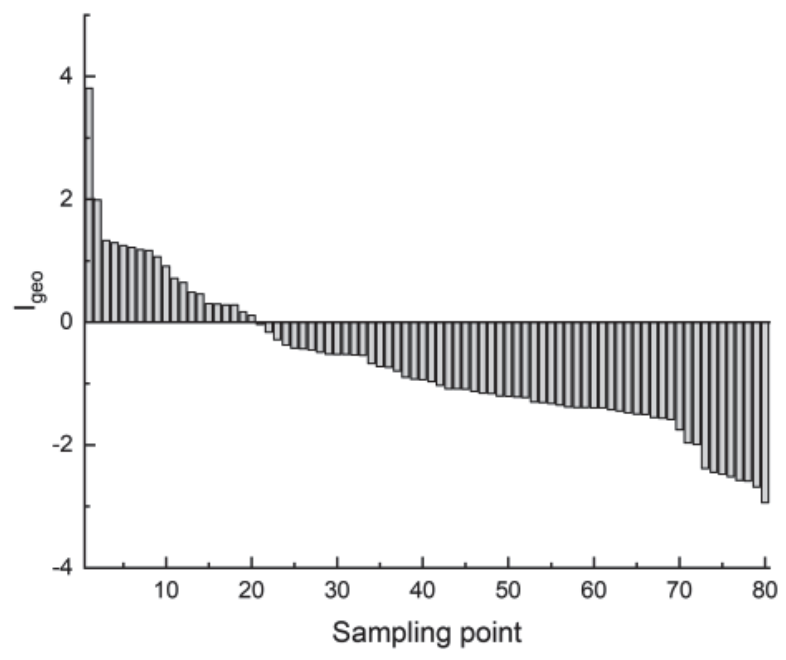

Fig. 5. Descending chart of the ground accumulation index.

According to the urban layout of Changchun City, its thermal power group is mainly located in the southeastern section of the main urban area. The pollutants generated by winter heating mainly occur in that area, and the prevailing northwest winds during the winter seasons also cause the mercury pollutants to migrate from the northwest to the southeast. In addition, according to the dominant wind directions in Changchun City, the mercury pollution levels in the soil are direct results of the wind directions. This study's sampling time was in early April, when Changchun City was experiencing prevailing southwesterly winds. Those winds caused the atmospheric mercury pollution to be transported through rain and snow into the corresponding regional soil. Then, under the effects of rain and snow water leaching, the accumulation levels of the soil water-soluble $\mathrm{Hg}^{2+}$ had increased with the surface runoff erosion, or had seeped more deeply into

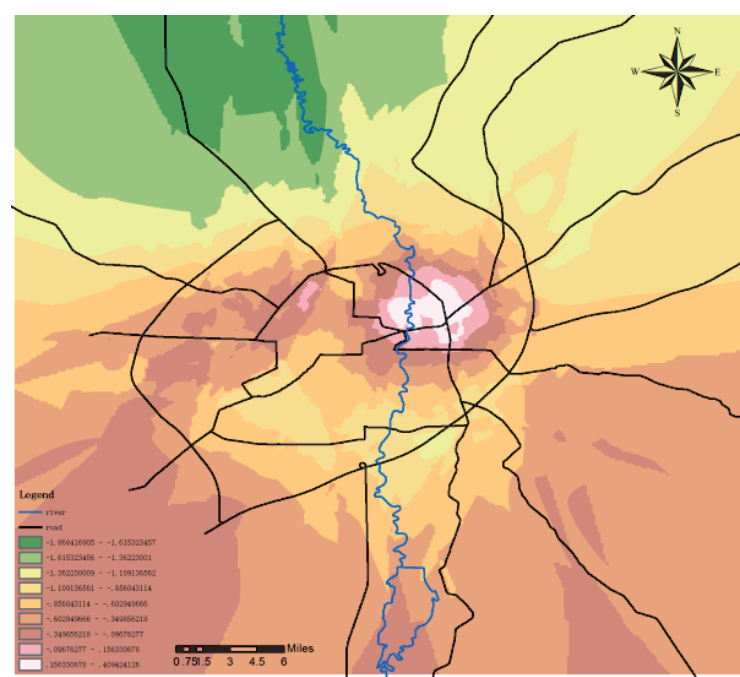

Fig. 6. Distribution of the soil mercury accumulation pollution index $\left(I_{g e o}\right)$ in Changchun City. the soil layers [76]. Therefore, the southwestern wind direction on the surface soil had resulted in the mercury concentrations becoming significantly higher than those under the other wind conditions. Consequently, the mercury content in the surface soil layers was observed to gradually increase from the southwest to the northeast in the study area. However, it was determined in this study that the mercury content in the soil of the region was not only influenced by the meteorological conditions (dominant wind directions), but also by the surrounding topography [76]; physical and chemical properties of soil [77]; and human activities and other factors.

\section{Evaluation of the Soil Mercury Pollution Levels in Changchun City}

\section{Ecological Risk Assessments of the Soil Mercury Pollution}

In the present research investigation, the descending order table and distribution diagram of the ground accumulation index (Fig. 5 and Fig. 6) were obtained using a ground accumulation pollution index method.

According to the results obtained in this research study, $25.0 \%$ of the sample points in Changchun City were polluted (index $>0$ ). Among those points, only one point was found to be strongly polluted; $10.0 \%$ of the sampling points were moderately polluted; $13.8 \%$ of the sampling points were non-polluted to moderately polluted; and the remainder of the sample points were considered to be not polluted. As detailed in Fig. 6, the polluted areas were mainly concentrated in the southwestern and southeastern regions of Changchun City. Also, there was some pollution detected in the northeastern region, which was consistent with the analysis results of the wind directions. Due to the existence of an industrial park, thermal plant, and

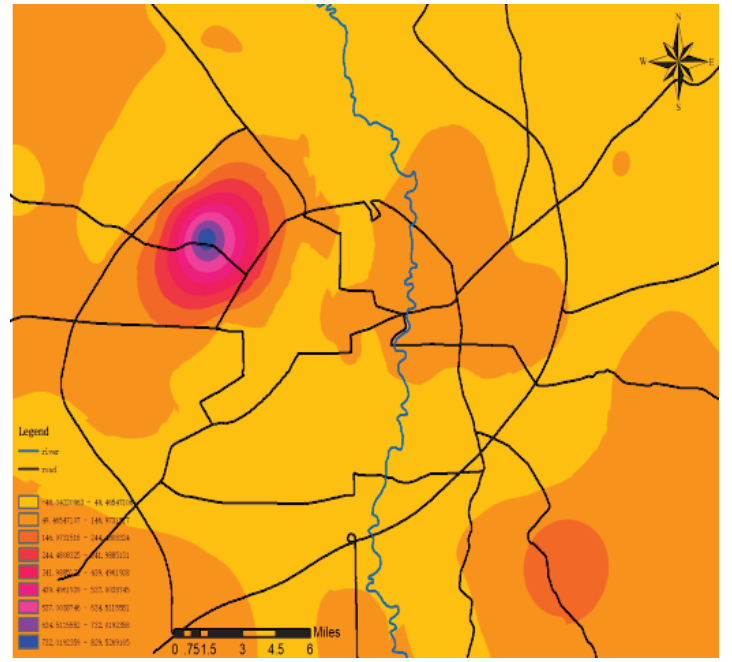

Fig. 7. Distribution of the soil mercury potential ecological risk assessment index $(E r)$ in Changchun City. 
medical machinery plant, the content levels of mercury in the soil of the aforementioned areas were relatively high. It was also observed that industrial park, thermal plant, and medical machinery plant were in fact the main sources of the mercury pollution. In addition, due to the influences of the dominant wind direction (southwest), there was also some pollution detected in the northeastern section of the study area. Due to the large number of logistic parks distributed in the northeastern section, their cumulative index was much higher than that of the other locations in the study area, which indicated that logistic traffic had significantly contributed to the urban soil mercury pollution. Overall, the ground accumulation index of the mercury content levels in the soil of Changchun City revealed no pollution to moderate pollution levels, which indicated that the overall mercury pollution degree was not high, and mainly concentrated in some specific areas. However, if no control measures are taken, then the safety of the ecological environment will potentially be threatened.

According to the evaluation standard of the potential ecological risk index method (Fig. 7), the potential ecological risk levels of the northwestern and southeastern sections of Changchun City were higher than those of the other two directions, with $41.3 \%$ of the sampling points found to have moderate or above potential ecological risk levels (index $>40$ ). Two of the potential ecological risk indexes were as high as 840.8 and 238.4, respectively, which represented relatively extreme potential ecological risks and were rated as serious. The reason for these high index results may have been that those two points were located near an industrial park, and the industrial waste residue and other pollutants may have polluted the soil at those locations, resulting in abnormal mercury content levels. It was also revealed that $15.0 \%$ of the samples had high levels of potential ecological risk; $23.8 \%$ of the sampling sites had medium levels of potential ecological risk; and the remainder were observed to have low levels of potential ecological risk, accounting for $57.5 \%$. Therefore, generally speaking, this study found that that the soil mercury contamination levels in Changchun City presented low ecological risk potential.

\section{Assessment of the Potential Health Risks of Soil Mercury Contamination}

As can be seen in Fig. 8, the order of the daily exposure and non-carcinogenic risk coefficient under the different exposure pathways was as follows: Intake of steam $>$ oral intake $>$ skin contact $>$ respiratory pathways. In addition, the intake of mercury vapor was determined to be the main factor affecting the health risks of heavy metal mercury exposure. Also, the spatial distribution order of the two was northwest $>$ southeast $>$ northeast $>$ southwest, with the non-carcinogenic risks determined to be far less than 1 .

In the present study, the $H I$ was calculated by the $A D I$ and $H Q$, and its distribution is detailed in Fig. 9. As can be seen in the figure, the spatial distribution of the total non-carcinogenic risk assessment index $(H I)$ was northwest $>$ southeast $>$ sou thwest $>$ northeast. It was revealed that, depending on the analysis results, the southwestern section of the study area was mainly industrial, and the total health risk value was low, since the southwestern section was located in the upwind direction. However, in the northeastern section, logistic parks were concentrated and located in the downwind direction, resulting in the total health risk values being slightly lower. The study area's thermal power companies were mainly located in the southeastern section. Another factor was that coal burning processes were more common than that in the southwestern and northeastern section, and with coal burning being one of the important sources of exogenous mercury, the total health risk values were higher in the northeastern section. Moreover, there were cement factories, medical equipment factories, and logistic parks located in the northwest, and the absolute health risk value was slightly higher. Generally speaking, the average value in each direction was determined to be much less than 1 . Therefore, it was considered that the soil mercury accumulation had not a)

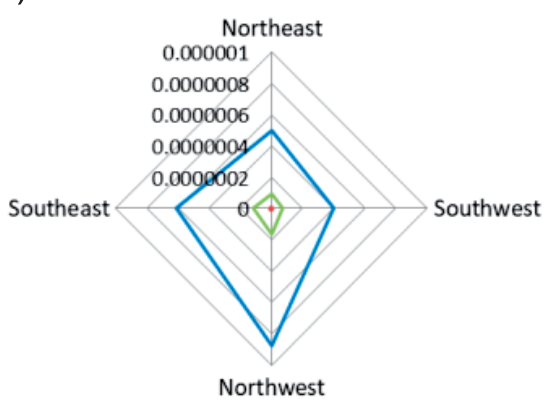

b)

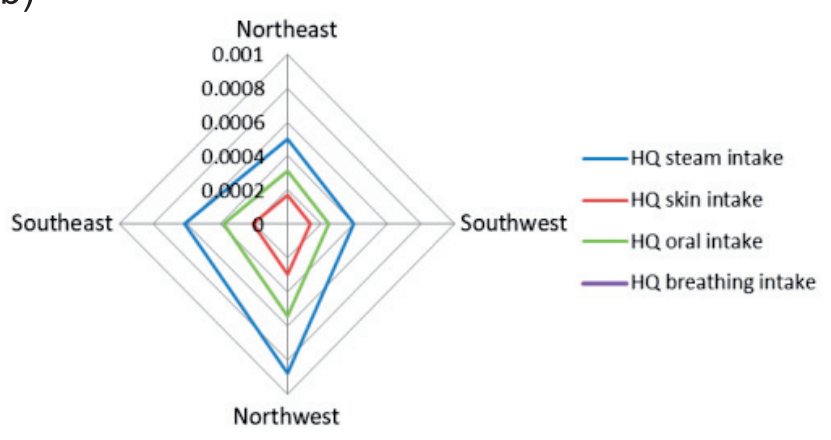

Fig. 8. a) Daily exposure amounts $(A D I)$; and b) non-carcinogenic risk coefficient $(H Q)$ of the mercury content in the soil in Changchun City under different exposure routes. 


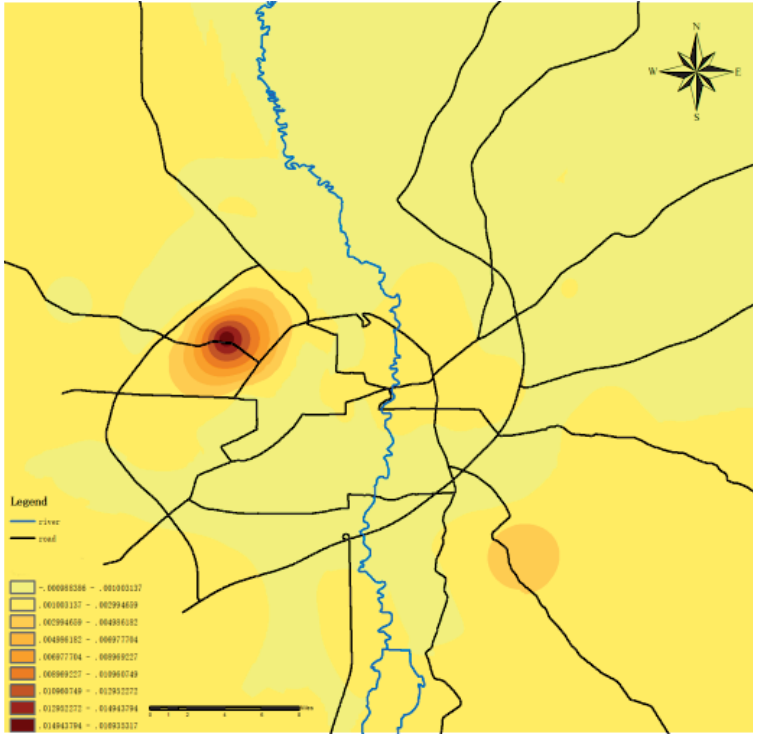

Fig. 9. Distribution of the total non-carcinogenic risk assessment index $(H I)$ of the soil mercury content in Changchun City.

yet reached levels which were harmful the health of the resident adults.

As can be seen in Figs 8 and 9, the health risks and total health risk values of all the approaches were far less than 1, which indicated that the soil mercury contamination in the study area was not harmful to the health of the local adults. However, the northwestern section of the study area had displayed certain potential risks due to its higher observed values.

\section{Conclusions}

The average mercury content of the soil in the main urban areas of Changchun City was $(0.0569 \pm 0.103)$ $\mathrm{mg} / \mathrm{kg}$, and the concentration range was determined to be between 0.0052 and $1.3240 \mathrm{mg} / \mathrm{kg}$. This study found that the mercury content levels in nearly $70 \%$ of the examined soil samples had exceeded the background value of the soil. There was observed to be a direct correlation between the atmospheric mercury concentrations at $0 \mathrm{~cm}$ and the soil mercury content levels $(\mathrm{P}=0.000532)$. In addition, extremely significant correlations were observed between the atmospheric mercury content distributions at $0 \mathrm{~cm}$ and $100 \mathrm{~cm}$ $(\mathrm{P}=0.000524)$.

It was found that according to the evaluation results obtained using a local cumulative pollution index method, $25 \%$ of the sample points in Changchun City were considered to be polluted, and the unsanitary areas were mainly concentrated in the southwestern and southeastern regions of Changchun City. Overall, the soil mercury accumulation index indicated a range of pollution-free to moderate pollution in Changchun City. Also, the evaluations conducted using a potential ecological risk index method revealed that the potential ecological risk levels in the northwestern and southeastern sections of Changchun City were greater than those in the other two directions. Generally speaking, the soil mercury contamination levels in Changchun City were found to currently present low ecological risks. In addition, through this study's calculations of the next day exposure levels of the different exposure pathways, it was determined that the intake of mercury vapor was the principal factor of the health hazards related to heavy metal mercury. The average values of the non-carcinogenic risks $(H Q)$ and the total non-carcinogenic risk assessment index $(H I)$ in the four examined directions in Changchun City were found to be far less than 1 . Therefore, it was concluded that the soil mercury contamination levels were not currently at the levels which could be considered to be harmful to the health of the resident adults. However, it should be noted that the northwestern section of the study area had displayed certain potential cancer risks due to its high risk values.

\section{Acknowledgements}

This study was funded by the Chinese National Natural Science Foundation of China (Grant Nos. 31230012, 31770520); and Key Social Development Project of Jilin Science and Technology Department of China (Grant No. 20190303068SF). We are also grateful to the Key Laboratory of Vegetation Ecology of the Ministry of Education for its help and support.

\section{Conflict of Interest}

The authors declare no conflict of interest.

\section{References}

1. DRISCOL C.T., MASON R.P., Chan H.M., JACOB D.J., PIRRONE N. Mercury as a Global Pollutant: Sources, Pathways and Effects. Environmental Science \& Technology, 47 (10), 4967, 2013.

2. LIU L.Y., CHEN Y., FENG Q.Z., LI Y., WANG J.F., LI Z., WEI S.H., FU X. Pollution Characteristics and Risk Evalution of Mercury, Lead and Cadmium in Soil of Mercury Tailings. Proceedings of the 2018 National Academic Annual Conference of Environmental Engineering, China 2 (36), 904, 2018.

3. WANG G., LIU H.Q., Gong Y., WEI Y., MIAO A.J., YANG L.Y., ZHONG H. Risk Assessment of Metals in Urban Soils from a Typical Industrial City, Suzhou, Eastern China. Environmental Research and Public Health, 14 (9), 1025 , 2017.

4. WANG Z.J., ZHANG G., CHEN X.B., ZHAO Q.J., WANG W.Y., SHENG L.X., BIAN H.F., LI Z.X., WANG D.L. Measurementt and Scaling of Mercury on Soil and Air in a Historical Artisanal Gold Mining Area in Northeastern China. Chinese Geographical Science, 29 (2), $245,2019$. 
5. ZHANG S.A., TANG J.W., ZHENG H.Y., XUE Y.H., ZHENG X.Q. Pollution characteristics and risk assessments of mercury in wastewater-irrigated paddy fields. China Environmental Science, 35 (9), 2729, 2015.

6. ZHAO X., HUANG Y., LI J., CHENG G., SONG L.H., LU K.D., NING C. Environmental Levels, Spatial Distribution, Sources and Potential Ecological Risk of Heavy Metals in Soils Surrounding A Large Solid Waste Incinerator. Ecology and Environmental Sciences, 24 (6), 1013, 2015.

7. LU S.J., WANG Y.Y., HE L.H. Heavy Metal pollution and Ecological Risk Assessment of the Paddy Soils around A $\mathrm{Pb}-\mathrm{Zn}$ Mine in Huize Country. Ecology and Environmental Sciences, 23 (11), 1832, 2014.

8. PAN L.B., WANG Y., Ma J., HU Y., SU B.Y., FANG G.L., WANG L., XIANG B. A review of heavy metal pollution levels and health risk assessment of urban soils in Chinese citys. Environmental Science and Pollution Research, 25, $1055,2018$.

9. FENG X.B., CHEN J.B., FU X.W., HU H.Y., ZHU W. Progresses on Environmental Geochemistry of Mercury. Bulletin of Mineralogy, Petrology and Geochemistry, 32 (5), 503, 2013.

10. WANG Q, ZHANG Z.S., ZHOU X.H., LU X.G. Mercury Distribution and Accumulation in Typical Wetland Ecosystems of Sanjiang Plain, Northeast China. Chinese Geographical Science, 23 (1), $49,2013$.

11. LI R.X., YUAN Y., Li C.W., SUN W., YANG M., WANG X.R. Environmental Health and Ecological Risk Assessment of Soil Heavy Metal Pollution in the Coastal Cities of Estuarine Bay - A Case Study of Hangzhou Bay, China. Toxics, 8 (3), 75, 2020.

12. CABRAL PINTO M.M.S., SILVA MARIA M.V.G., FERREIRA DA SILVA E.A., DINIS P.A., ROCHA F. Transfer processes of potentially toxic elements (PTE) from rocks to soils and the origin of PTE in soils: A case study on the island of Santiago (Cape Verde). Journal of Geochemical Exploration, 183 (B), 140, 2017.

13. CABRAL PINTO M.M.S., FERREIRA DA SILVA E.A., SILVA M.M.V.G., MELO-GONCALVES P. Heavy metals of Santiago island (Cape Verde) top soils: Estimated background value maps and environmental risk assessment. Journal of African Earth Sciences, 101, 162, 2015.

14. CABRAL PINTO M.M.S., FERREIRA DA SILVA E.A., SILVA M.M.V.G., CARLA C. Environmental risk assessment based on high-resolution spatial maps of potentially toxic elements sampled on stream sediments of Santiago, Cape Verde. Geosciences, 4 (4), 297, 2014.

15. ONAT N.C., KUCUKVAR M., TATARI O. ScopeBased Carbon Footprint Analysis of US. Residential and Commercial Buildings: An Input Output Hybrid Life Cycle Assessment Approach. Building and Environment, 72 (2), 53, 2014.

16. XUE Y., CHARLES T.D., RICHARD A.F.W., MARIO M., CHRIS E.J. Soil Mercury and Its Response to Atmospheric Mercury Deposition Across the Northeastern United States. Ecological Applications, 24 (4), 812, 2014.

17. YIN R.S., GU C.H., FENG X.B., HURLEY J.P., KRABBENHOFT D.P., LEPAK R.F., ZHU W., ZHENG L.R., HU T.D. Distribution and Geochemical Speciation of Soil Mercury in Wanshan $\mathrm{Hg}$ Mine: Effects of Cultivation. Geoderma, 272 (15), 32, 2016.

18. XU F.Y., HU Y.Y., BAO B., CHEN X. Distribution Characters and Pollution Evaluation of $\mathrm{Hg}$ in Urban Soils of Different Functional Area in Chongqing. Chinese Journal of Soil Science, 46 (5), 1253, 2015.

19. MANTA D.S., ANGELONE M., BELLANCA A., NERI R., SPROVIERI M. Heavy metals in urban soils: a case study from the city of Palermo (Sicily), Italy. Science of the Total Environment, 300, 229, 2002.

20. KOT F.S., MATYUSHKINA L.A. Distribution of mercury in chemical fractions of contaminated urban soils of Middle Amur, Russia. Journal of Environmental Monitoring, 4 (5), 803, 2002.

21. RODRIGUES S., PEREIRA M.E., SARABANDO L., LOPES L., CACHADA A., DUARTE A. Spatial distribution of total $\mathrm{Hg}$ in urban soils from an Atlantic coastal city (Aveiro, Portugal). The Science of the Total Environment, 368 (1), 40, 2006.

22. FANG F.M., WANG Q.C., LI J.F. Urban environmental mercury in Changchun, a metropolitan city in Northeastern China: source, cycle and fate. Science of the Total Environment, 330 (1), 159, 2004.

23. FEI X.F., LOU Z.H., XIAO R., REN Z.Q., LV X.N. Contamination assessment and source apportionment of heavy metals in agricultural soil through the synthesis of PMF and Geog Detector models. Science of the Total Environment, 747, 141293, 2020.

24. BI X.Y., ZHANG M.H., WU Y.J., FU ZB., SUN G.Y., SHANG L.H., LI Z.G., WANG P.C. Distribution patterns and sources of heavy metals in soils from an industry undeveloped city in Southern China. Ecotoxicology and Environmental Safety, 205 (1), 11115, 2020.

25. MIGUEL E.D., IRIBARREN I., CHACON E., ORDOEZ A., CHARLESWORTH S. Risk-based evaluation of the exposure of children to trace elements in playgrounds in Madrid (Spain). Chemosphere, 66 (3), 505, 2007.

26. QU C.S., MA Z.W., YANG J., LIU Y., BI J., HUANG L. Human exposure pathways of heavy metals in a lead-zinc mining area, Jiangsu Province, China. PLoS One, 7 (11), $1,2012$.

27. CAO S.Z., DUAN X.L., ZHAO X.G., CHEN Y.T., WANG B.B., SUN C.Y., ZHENG B.H., WEI F.S. Health risks of children's cumulative and aggregative exposure to metals and metalloids in a typical urban environment in China. Chemosphere, 147, 404, 2016.

28. KHAN S., MUNIR S., SAJJAD M., LI G. Urban park soil contamination by potentially harmful elements and human health risk in Peshawar city, Khyber Pakhtunkhwa, Pakistan. Journal of geochemical Exploration, 165, 102, 2016.

29. GOPE M., MASTO R.E., GEORGE J., HOQUE R.R., BALACHANDRAN S. Bioavailability and health risk of some potentially toxic elements $(\mathrm{Cd}, \mathrm{Cu}, \mathrm{Pb}$ and $\mathrm{Zn})$ in street of Asansol, India. Ecotoxicology and Environmental Safety environment, 138, 231, 2017.

30. WANG D.H., WANG Y.J., ZHAO X.L. Distribution Characteristics of Soil Mercury around Inner Mongolia Steppe Coal Mine Area. Earth and Environment, 47 (2), 170, 2019.

31. LI J.J., ZHENG J.H. Distribution Characteristics and Pollution Assessment of Mercury in Farmland Soils of Different Regions in Zhongshan City. Journal of MUC (Natural Sciences Edition), 25 (4), 5, 2016.

32. JIN S., XU H., ZHUANG X.R., WANG Y. Occurrence phases and pollution characteristics of mercury in soil of Qixing District of Guilin City. Mineral Resources and Geology, 30 (2), 302, 2016.

33. ZHAO L., XU Y.F., HOU H., SHANGGUAN Y.X., LI F.S. Source identification and health risk assessment of metals 
in urban soils around the tanggu chemical industrial district, Tianjin, China. Total Environment, 468-469, 654, 2014.

34. PAN L.B., MA J., HU Y., SU B.Y., FANG G.L., WANG Y., WANG Z.S., WANG L., XIANG B. Assessments of levels, potential ecological risk, and human health risk of heavy metals in the soils from a typical county in Shanxi Province, China. Environ. Environmental Science and Pollution Research, 23 (19), 19330, 2016.

35. WANG H., SUN L., LIU Z., LUO Q. Spatial Distribution and Seasonal Variations of Heavy Metal Contami-nation in Surface Waters of Liaohe River, Northeast China. Chinese Geographical Science, 27 (1), 52, 2017.

36. HUANG X.M., ZHANG X.Q., MIN J.M., LIU Q., ZHANG S.J., BAI L.Y., DAI J.L. Investigation and Evaluation of Heavy Metal Environment in Farmland Soil around a Steelmaking Plant in North China. TianJin Science \& Technology, 47 (9), 76, 2020.

37. 3CHRISTOPHORIDIS C., EVGENAKIS E., BOURLIVA A., LAMBRINI P., KONSTANTIONS F. Concentration, fractionation, and ecological risk assessment of heavy metals and phosphorus in surface sediments from lakes in N. Greece. Environmental Geochemistry and Health, 42 (9), 2747, 2020.

38. JI Y.Q., FENG Y.C., WU H.H., ZHU T., BAI Z.P., DUAN C.Q. Using geo accumulation index to study source profiles of soil dust in china. Journal of Environmental Sciences-China, 20 (5), 571, 2008.

39. LIU K.H., LI C.M., TANG S.Q., SHANG G.D., YU F.M., LI Y. Heavy metal concentration, potential ecological risk assessment and enzyme activity in soils affected by a lead-zinc tailing spill in Guangxi, China. Chemosphere, 251, 126415, 2020

40. WANG Q.C., FANG F.M., LI Z.B. Exchange flux of mercury on the interface exchange in Changchun City. China Environmental Science, 25 (4), 475, 2005.

41. PIAO Y., LIU M.S. Causes of The Compound Pollutions in Changchun City and Strategies. Journal of EMCC, 26 (6), 86, 2016

42. SHEN M.N., HAN X.K., KANG C.Y., LI N. Ecological Risk Assessment of Soil Heavy Metal Pollution in Different Function Areas in Changchun. Industrial Safety and Environmental Protection, 44 (10), 102, 2018.

43. GAO L.J., MAO K., ZHANG W., CUI Z.K., LU B.Q., HUANG G.P., ZHANG J.F., FENG X.B., ZHANG H., SHANG L.H. Temporal and Spatial Distribution and Pollution Characteristics of Mercury in Paddy Soils of the Wanshan Mercury Mining Area, Guizhou Province. Bulletin of Mineralogy, Petrology and Geochemistry, 39, $1,2020$.

44. SABOUHI M., ALI-TALESHI M.S., BOURLIVA A., NEJADKOORKI F., STEFANIA S. Insights into the anthropogenic load and occupational health risk of heavy metals in floor dust of selected workplaces in an industrial city of Iran. The Science of the total environment, 744, 140762, 2020.

45. MENG X.X., LI S.Z. Background value of soil elements in Jilin province. Beijing: Science press, 64, 1995.

46. MAANAN M., SADDIK M., MAANAN M., CHAIBI M., ASSOBHEI O., ZOURARAH B. Environmental and ecological risk assessment of heavy metals in sediments of Nador Lagoon, Morocco. Ecological Indicators, 48, 616, 2015.

47. XU Z.Q., Ni SJ, TUO X.G., ZHANG C.J. Calculation of Heavy Metals' Toxicity Coefficient in the Evaluation of
Potential Ecological Risk Index. Environmental Science \& Technology, 31 (2), 112, 2008.

48. WEI F.S., CHEN J.S. Research on the background values of soil in China. Environmental Science, 4, 12, 1991.

49. LIU Y., LEI S.G., CHEN X.Y. Assessment of heavy metal pollution and human health risk in urban soils of a coal mining city in east China. Human and Ecological Risk Assessment, 22 (6), 1359, 2016.

50. CHEN B., Qiu H.Y., GUO Y.N., WANG L.Y., WANG X. Heavy Metal Contamination and Health Risk Assessment in the Zinc Mine Set Area of Youxi, China. Journal of Xiamen University(Natural Science), 51 (2), 245, 2012.

51. ISLAM M.S., AHMED M.K., HABIBULLAH-ALMAMUN M., EATON D.W. Human and ecological risks of metals in soils under different land use in an urban environment of Bangladesh. Pedosphere, 2017.

52. HU B., WANG J., JIN B., LI Y., SHI Z. Assessment of the potential health risks of heavy metals in soils in a coastal industrial region of the Yangtze River delta. Environmental Science and Pollution Research, 24 (24), 19816, 2017.

53. BOURLIVA A., PAPADOPOULOU L., AIDONA E., GIOURI K., SIMEONIDIS K., VOURLIAS G. Characterization and geochemistry of technogenic magnetic particles (TMPS) in contaminated industrial soils: Assessing health risk via ingestion. Geoderma, 295, 86, 2017.

54. LI F., ZHANG J.D., JIANG W., LIU C.Y., ZHANG Z.M., ZHANG C.D., ZENG G.M. Spatial health risk assessment and hierarchical risk management for mercury in soils from a typical contaminated site, China. Environmental Geochemistry and Health, 39 (4), 923, 2017.

55. DU Y.R., GAO B., ZHOU H.D., JU X.X., HAO H., YIN S.H. Health risk assessment of heavy metals in road dusts in urban parks of Beijing, China. Procedia Environmental Sciences, 18, 299, 2013.

56. VILAVERT L., NADAL M., SCHUHMACHER M., DOMINGO J.L. Concentrations of metals in soils in the neighborhood of a hazardous waste incinerator: assessment of the temporal trends. Biological Trace Element Research, 149 (3), 435, 2012.

57. TANG R.L., MA K.M., ZHANG Y.X., MAO Q.Z. Health risk assessment of heavy metalsof street dust in Beijing. Acta Scientiae Circumstantiae, 32 (8), 2006, 2012.

58. U.S. Environmental Protection Agency (USEPA). Supplemental Guidance for Developing Soil Screening Levels for Superfund Sites; U.S. Environmental Protection Agency: Washington, DC, USA, 2002

59. Beijing environmental protection bureau. Guidelines for site environmental assessment. Beijing, 2009.

60. LI Z.P., CHEN Y.C., YANG X.C., WEI S.Q. Assessment of potential ecological hazard of heavy metals in urban soils in Chongqing city. Journal of Southwest Agricultural University (Natural Science), 28 (2), 227, 2006.

61. HAN P., WANG J.P., FENG X.Y., MA Z.H., LU H.X., WEI L., YAN L.B. Ecological Risk Assessment of Heavy Metals in Soils in Shunyi, Beijing. Journal of AgroEnvironment Science, 34 (1), 103, 2015.

62. GUO C.H., WANG Y.G., REN Y.P. The distribution characteristics of Hg-element content in the surface soil in Taiyuan. Journal of Shanxi University (Nat. Sci. Ed.), 19 (3), 339, 1996.

63. ZHU C.J., ZHANG Y.Q., LIU M., CHEN L.G., HE Q.S., YE Z.X., SUN J.R. Distribution and Pollution Assessment of the Mercury in Soils of Tibet. Ecology and Environmental Sciences, 23(9), 1487, 2014. 
64. ZHANG X.P. Research on the environmental background values of soils in Xizang. Scientia Geographica Sinica, 4 (1), 49, 1994

65. XIA Z.L., MU C.R., LI S.Z., HE R.Z. Preliminary analysis of the natural content and differentiation of mercury in some soil types profiles in China. Chinese science bulletin, 3, 89, 1985.

66. HUANG S.S., WU X.M., YAN C.Y. Heavy Metal Concentrations and Their Spatial Distribution in Urban Soils of Nanjing. Urban Environment\& Urban Ecology, 20 (2), 1, 2007.

67. ZHANG X.X., ZHA T.G., GUO X.P., MENG G.X., ZHOU J.X. Spatial distribution of metal pollution of soils of Chinese provincial capital cities. Science of the Total Environment, 643, 1502, 2018.

68. YANG Z.P., LU W.X., LIU X.R., XIN X. Sources Identification of Heavy Metals in Urban Soil of Changchun Based on Principal Component Analysis. Urban Environment \& Urban Ecology, 5, 29, 2009.

69. LIU Q., WANG Y., LIU J.S., WANG Q.Y., ZOU M.Y. Grain-size distribution and heavy metal contamination of road dusts in urban parks and squares in Changchun, China. Environmental Geochemistry and Health, 37 (1), 71, 2015.

70. FENG Z.X., WANG S.J., JIN S.H., YANG J. Effects of urban morphology and wind conditions on land surface temperature in Changchun. Acta Geographica Sinica, 74 (5), 902, 2019
71. ZHOU B., RYBSKI D., KROPP J.P. The role of city size and urban form in the surface urban heat island. Scientific Reports, 7 (1), 1, 2017.

72. ZHU L., MIAO J.F. Overview of Urban Breeze Circulation Studies in china. Meteorological Science and Technology, 47 (1), 52, 2019.

73. WANG D.Y., SHI X.H., YANG X.C. Transformation of Atmospheric Mercury in Soil and Its Influenceon the Accumulation of Mercury in Soil. Chongqing Environmental Science, 20 (5), 22, 1998.

74. SHEN Q.X., LI C.G., SUN Y.A., SONG Y.T. Evolution of New Urban Space Based on the Use Land and Population Analysis-A Case Study of Changchun. Economic Geogrphy, 38 (6), 44, 2018.

75. TANG J., ZHONG Y.P., WANG L. Background value of soil heavymetal in the Three Gorges Reservoir District. Chinese Journal of Eco-Agriculture, 16 (4), 848, 2008

76. DANIEAL S.M., MASSIMO A., ADRIANA B., RODOLFO N., MARIO S. Heavy Metals in Urban Soil: A Case Study from the City of Palermo (Sicily), Italy. The Science of the Total Environment, 300 (1), 229, 2002.

77. LIU H.Y., XIE Z.R., CHEN D.Y., ZHOU X.M., FENG X.M., GUO K.Y. Primary assessment of environmental quality of soils in Chengdou Area. Acta Scientiae Circumstantiae, 24 (2), 29, 2004. 